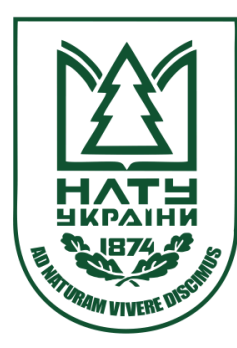

Науковий вісник НлтУ України

Scientific Bulletin of UNFU

ISSN 1994-7836 (print)

https://nv.nltu.edu.ua

https://doi.org/10.36930/40310511

Article received 12.1.2021 p.

Article accepted 25.11.2021 p.

UDC 504.4.054:351.777

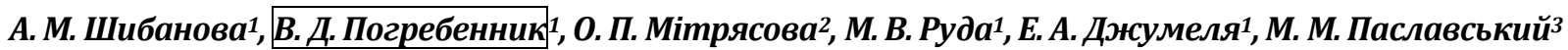

${ }^{1}$ Національний університет "Львівська політехніка", м. Львів, Украӥна

${ }^{2}$ Чорноморський національний університет ім. Петра Могили, м. Миколаїв, Україна

${ }^{3}$ Національний лісотехнічний університет України, м. Львів, Україна

\title{
ЕКОЛОГІЧНЕ ОЦІНЮВАННЯ ЯКОСТІ ВОДИ РІЧКИ ДНІСТЕР
}

Басейн річки Дністер належить до регіонів з високим ступенем господарського освоєння природних ресурсів та інтенсивною і довготривалою їх експлуатацією, тому на сьогодні особливо актуальним $\epsilon$ різнобічне вивчення проблем якості водних ресурсів. У цьому дослідженні оцінено екологічний стан річки Дністер. Проаналізовано значення гідрохімічних показників якості води на постах спостереження по течії річки Дністер, починаючи з верхів'я річки і завершуючи долиною Дністра. Встановлено перевищення гранично допустимих концентрацій за вмістом нітрит-іонів, сульфат-іонів, хлорид-іонів, амоній-іонів та показником біохімічного споживання кисню у контрольних створах річки на окремих постах спостереження. За даними середньорічних концентрацій забруднювальних речовин у контрольних створах водних об'єктів регіону за звітний рік розраховано індекс забрудненості води та встановлено клас якості води у створах сіл Розвадів Львівської області та Маяки Одеської області. Оцінювання за індексом забрудненості води дає змогу виконати порівняння якості води різних водних об'єктів між собою, незалежно від наявності різних забруднювальних речовин, виявити тенденцію змін в якості води в часі. Проведено порівняльну характеристику якості води за розрахованим індексом забрудненості води у контрольних створах річки Дністер на вказаних постах спостереження. Встановлено, що для верхів'я річки Дністер (с. Розвадів Львівської області) характерні значно вищі значення індексу забрудненості води порівняно з долиною Дністра (с. Маяки Одеської області). Виявлено, що води басейну річки Дністер здебільшого помірно забруднені та перебувають під значним антропогенним впливом, рівень якого близький до межі стійкості екосистем. За визначеними значеннями індексу забрудненості води, можна вважати, що вода Дністра ще не досягла критичної межі забруднення і має потенціал до самоочищення.

Ключові слова: річка Дністер; пости спостереження; індекс забрудненості води; клас якості води.

\section{Вступ / Introduction}

Основою для досягнення стійкого збалансованого розвитку будь-якої території $є$ не тільки наявність певної кількості водних ресурсів, але й їхня відповідна якість.

Різнобічне вивчення проблем природокористування особливо актуальне для регіонів 3 високим ступенем господарського освоєння природних ресурсів та інтенсивною і довготривалою їх експлуатацією. Саме до таких районів належить басейн Дністра.

Дністер - одна з великих річок України і найбільша річка Молдови, яка разом з Дунаєм, Дніпром і Південним Бугом належить до басейну Чорного моря. Загальна довжина річки - 1350 км, площа басейну - понад 72 тис. км². Дністер бере початок у Карпатах на висоті 911 м н.р.м. і впадає у Дністровський лиман - затоку Чорного моря, відокремлену від нього вузькою косою. На північному заході басейн Дністра межує з басейном Вісли, на півночі - Дніпра, на південному сході - Південного Бугу, на заході і південному заході - Дунаю 3 Тисою, Прутом і малими річками.

Екстенсивний характер природокористування у басейні Дністра за останні роки призвів до значного виснаження його водних ресурсів та погіршення екологічного стану поверхневих вод.

Для збереження якості природних водних об'єктів, передусім, необхідно вживати заходів зі запобігання їх забрудненню. Будь-які стічні води перед спуском у від-

\section{Інформація про авторів:}

Шибанова Алла Миколаївна, канд. техн. наук, доцент, кафедра екологічної безпеки та природоохоронної діяльності. Email: ashybanova16@gmail.com; https://orcid.org/0000-0003-0364-7056

Погребенник Володимир Дмитрович, д-р техн. наук, професор, кафедра екологічної безпеки та природоохоронної діяльності. Email: vpohreb@gmail.com; https://orcid.org/0000-0002-1491-2356

Мітрясова Олена Петрівна, д-р хім. наук, професор, кафедра екологіï. Email: eco-terra@ukr.net; https://orcid.org/0000-0002-9107-4448

Руда Марія Віталіївна, канд. техн. наук, доцент, кафедра екологічної безпеки та природоохоронної діяльності. Email: marichkarmv@gmail.com; https://orcid.org/0000-0003-0590-4589

Джумеля Ельвіра Анатоліївна, канд. техн. наук, асистент, кафедра програмного забезпечення. Email: elviradzhumelia@gmail.com; https://orcid.org/0000-0003-3146-8725

Паславський Михайло Михайлович, канд. техн. наук, асистент, кафедра інформаційних технологій. Email: mykhailo.paslavskyi@nltu.edu.ua; https://orcid.org/0000-0003-1635-4340

Цитування за Дсту: Шибанова А. М., Погребенник В. Д., Мітрясова О. П., Руда М. В., Джумеля Е. А., Паславський М. М. Екологічне оцінювання якості води річки Дністер. Науковий вісник НлТУ України. 2021, т. 31, № 5. С. 74-78.

Citation APA: Shybanova, A. M., Pohrebennyk, V. D., Mitryasova, O. P., Ruda, M. V., Dzhumelya, E. A., \& Paslavskyi, M. M. (2021). Ecological assessment of the Dnister river water quality. Scientific Bulletin of UNFU, 31(5), 74-78. https://doi.org/10.36930/40310511 
криті водойми потрібно очищувати. Оброблення стічних вод на очисних спорудах має забезпечувати такий ступінь очищення, що відповідає нормативним документам та встановленим ГДК.

Об'єкт дослідження - басейн річки Дністер та його приток.

Предмет дослідження - методи і засоби визначення показників якості води на постах спостереження по течії річки Дністер.

Мета дослідження - оцінити екологічний стан річки Дністер, що дасть змогу визначити місця підвищеної концентрації речовин у контрольних створах річки на окремих постах спостереження.

Для досягнення зазначеної мети визначено такі ocновні завдання дослідження: встановити ступінь перевищення ГДК показників якості води у контрольних створах річки на окремих постах спостереження; визначити клас якості поверхневих вод за індексом забрудненості води.

Наукова новизна отриманих результатів дослідження - виявлено закономірності зміни якості поверхневих вод по всьому басейну річки Дністер, зокрема визначено місця підвищеної концентрації речовин, які впливають на екологічний стан басейну річки.

Практична значущість результатів дослідження обгрунтовано передумови для зниження негативних наслідків антропогенного впливу на екологічний стан річки Дністер. Результати дослідження можуть бути використані для ефективного управління станом поверхневих вод басейну Дністра і відновлення його порушеної екосистеми.

Аналіз останніх досліджень та публікацій. Проведення систематичного екологічного моніторингу водойм $\epsilon$ необхідною умовою для контролю якості води і здатне забезпечити оперативне реагування в разі несанкціонованого надходження в навколишнє середовище забруднювальних речовин. У такий спосіб можна уникнути згубного впливу на навколишне середовище.

Систематизація та аналіз набутого досвіду розроблення узагальнювальних показників якості води й обгрунтування доцільності їх застосування у широкому спектрі наукових і практичних робіт з охорони водних ресурсів залишаються актуальним завданням. Оцінювання якості поверхневих вод $є$ надзвичайно важливим питанням, що висвітлюють у працях як зарубіжних вчених $[3,6,12,13,14]$, так і вітчизняних $[1,2,8,9,10,11]$. Вирішення цього питання дасть змогу уникнути поширення токсичних хімікатів і патогенних мікроорганізмів, погіршення якості питної води, зниження біопродуктивності поверхневих вод та їх здатності до самоочищення $[4,5,7,15]$.

Матеріали та методи досліджсення. Методику оцінювання якості води за комплексним показником індексом забрудненості води (I3В) - рекомендовано для використання підрозділам Держкомгідромету. Це одна із найпростіших методик комплексного оцінювання якості води. Оцінювання за показником ІЗВ дає змогу виконати порівняння якості води різних водних об'єктів між собою, незалежно від наявності різних забруднювальних речовин, виявити тенденцію змін в якості води в часі.

IЗВ розраховують за такою формулою:

$$
I 3 B=\frac{1}{n} \sum_{i=1}^{n} \frac{C_{i}}{\Gamma Д K_{i}}
$$

де: $C_{i}$ - середня концентрація $i$-го показника якості води; ГДК - гранично допустима концентрація $i$-го показника якості води.

Зазвичай IЗВ розраховують за шістьма-сімома гідрохімічними показниками, обов'язковими є: склад розчиненого кисню, водневий показник, біохімічне споживання кисню та ін. (табл. 1). Вихідними даними для виконання роботи слугували матеріали лабораторного аналізу води контрольних створів, проведених спеціалістами Департаменту екології та природних ресурсів у Львівській та Одеській областях.

Табл. 1. Критерії оцінювання якості вод за IЗВ /

Criteria for assessing water quality by WPI method

\begin{tabular}{|c|c|c|}
\hline Клас якості води & Величина ІЗВ & Текстовий опис \\
\hline I & $<0,3$ & Дуже чиста \\
\hline II & $>0,3-1$ & Чиста \\
\hline III & $>1-2,5$ & Помірно забруднена \\
\hline IV & $>2,5-4$ & Забруднена \\
\hline V & $>4-6$ & Брудна \\
\hline VI & $>6-10$ & Дуже брудна \\
\hline VII & $>10$ & Надзвичайно брудна \\
\hline
\end{tabular}

Для порівняння якості води у різних створах, визначення їх динаміки використовують як критерії класи якості води: до I класу належать води, на які найменше впливає антропогенне навантаження. Величини їх гідрохімічних і гідробіологічних показників близькі до природних значень для цього регіону; для вод II класу характерні певні зміни порівняно 3 природними, однак ці зміни не порушують екологічної рівноваги; до III класу відносять води, які перебувають під істотним антропогенним впливом, рівень якого близький до межі стійкості екосистем; води IV-VII класів - це води 3 порушеними екологічними параметрами, їх екологічний стан оцінюють як екологічний регрес.

\section{Результати дослідження та їх обговорення / Research results and their discussion}

Води Дністра і його басейну задовольняють потреби в технічному водопостачанні таких великих промислових вузлів, як Івано-Франківський концерн "Барва", ЗАТ "Лукор", Бурштинська ТЕС й ін. До територій $з$ найскладнішою екологічною ситуацією належать: Галицький район, де функціонує велетень енергетики Бурштинська ТЕC, Калуський - 3 хімічним підприємством ЗАТ "Лукор", Надвірнянський - з нафтопереробним заводом ВАТ "Нафтохімік Прикарпаття, не менш складна екологічна ситуація склалася у Тисменицькому районі, де функціонує ВАТ "Барва" та зосереджені промислові вузли обласного центру.

Стічні води та поверхневий стік "вливають" до водойми значну кількість завислих речовин і органічних сполук, внаслідок чого і підвищується кольоровість, знижується прозорість, збільшується біохімічне споживання кисню (БСК), зменшується кількість розчиненого кисню, підвищується концентрація азотовмісних речовин та хлоридів. Якість води насамперед залежить від природних чинників та рівня антропогенного навантаження на басейн річки. 3 огляду на це, оцінка якості основного джерела питного водопостачання - річки Дністер, має чи не найголовніше наукове і практичне значення.

Беручи до уваги масштаб басейну та кількість даних йому приток, можна прослідкувати динаміку змін фактичного значення хімічних речовин. Для прикладу було 
взято останні дані спостережень у містах та селах, які прилягають до басейну Дністра. Показники відображають зміну вмісту хімічних речовин та перевищення норм ГДК (ОБУВ) течією річки, починаючи з м. Самбір Львівської обл., завершуючи с. Кучургани Одеської області на семи постах спостереження у жовтні 2018 року.

Пост спостереження № 1. Повна назва поста спостереження: p. Дністер, 1278 км, м. Самбір, верхів'я р. Дністер, під мостом по дорозі м. Дрогобич; моніторинг здійснено лабораторією моніторингу вод та грунтів БУВР Західного Бугу та Сяну.

Пост спостереження № 2. Повна назва поста спостереження: p. Тисмениця, 21 км, м. Дрогобич, вплив стоків Дрогобицького промислового вузла, під мостом по дорозі Львів - Дрогобич; район річкового басейну: Дністер; моніторинг здійснено лабораторією моніторингу вод та грунтів БУВР Західного Бугу та Сяну.

Пост спостереження № 3. Повна назва поста спостереження: p. Сівка, 2 км, с. Сівка-Войнилівська, гирло, вплив стоків Калуського промислового вузла, 40 м нижче мосту по дорозі Галич - Залуква - Войнилів; район річкового басейну: Дністер; моніторинг здійснено лабораторією моніторингу вод та грунтів Дністровського БУВР.
Пост спостереження № 4. Повна назва поста спостереження: p. Дністер, 826 км, м. Хотин, лівий берег, 600 м вище мосту по дорозі Чернівці - Кам'янець-Подільський; район річкового басейну: Дністер; моніторинг здійснено басейновою лабораторією моніторингу вод та грунтів БУВР Пруту та Сірету.

Пост спостереження № 5. Повна назва поста спостереження: p. Дністер, 631 км, м. Могилів-Подільський, Вінницька область, міст, митний перехід з Молдовою; район річкового басейну: Дністер; моніторинг здійснено лабораторією моніторингу вод та грунтів БУВР Пруту та Сірету.

Пост спостереження № 6. Повна назва поста спостереження: р. Білоч, 15 км, с. Шершенці, кордон з Молдовою; район річкового басейну: Дністер; моніторинг здійснено лабораторією моніторингу вод та грунтів БУВР річок Причорномор'я та нижнього Дунаю.

Пост спостереження № 7. Повна назва поста спостереження: с. Кучургани, Кучурганське водосховище, на східному березі водосховища, 2 км нижче мосту через річку; район річкового басейну: Дністер; моніторинг здійснено лабораторією моніторингу вод і грунтів БУВР річок Причорномор'я та нижнього Дунаю (табл. 2).

Табл. 2. Дані з постів спостереження, розташованих по течії річки Дністер /

Data from observation posts located along the Dniester River

\begin{tabular}{|c|c|c|c|c|c|c|c|c|}
\hline \multirow{2}{*}{$\begin{array}{c}\text { Забруднювальна речовина / } \\
\text { показник }\end{array}$} & \multirow{2}{*}{$\begin{array}{c}\text { ГДК } \\
\text { (ОБУВ) }\end{array}$} & \multicolumn{7}{|c|}{ Пости спостереження } \\
\hline & & № 1 & № 2 & № 3 & № 4 & № 5 & № 6 & № 7 \\
\hline $\begin{array}{c}\text { Біохімічне споживання кисню } \\
\text { за } 5 \text { діб, мг О/дм }{ }^{3}\end{array}$ & 3 & 1,18 & 5,2 & 3,8 & 1,97 & 2,3 & 1 & 2,2 \\
\hline Завислі речовини, мг/дм ${ }^{3}$ & 15 & 3 & 3 & 69 & 14 & 12 & 40,5 & 29,8 \\
\hline Кисень розчинений, мг $\mathrm{O}_{2} /$ дм $^{3}$ & $>4$ & 8,03 & 5,87 & 12,5 & 13,4 & 8,23 & 2,33 & 11,5 \\
\hline Сульфат-іони, мг/дм ${ }^{3}$ & 100 & 34,61 & 89,82 & 184 & 82,2 & 57,8 & 97,92 & 427,49 \\
\hline Хлорид-іони, мг/дм ${ }^{3}$ & 300 & 24,32 & 210,18 & 210,18 & 37,2 & 22,17 & 26,59 & 465,00 \\
\hline Амоній-іони, мг/дм ${ }^{3}$ & 0,5 & 0,22 & 2,6 & 0,58 & 0,4 & 0,09 & 0,1 & 1,6 \\
\hline Нітрат-іони, мг/дм ${ }^{3}$ & 40 & 3,45 & 22,95 & 6,2 & 10,86 & 5,49 & 24,8 & 35,43 \\
\hline Нітрит-іони, мг/дм ${ }^{3}$ & 0,08 & 0,36 & 1,34 & 0,041 & 0,06 & 0,05 & 0,028 & 0,019 \\
\hline
\end{tabular}

Дані з поста спостереження м. Самбір (див. табл. 2) вказують на перевищення вмісту нітрит-іонів у 4,5 раза. Інші показники знаходяться в межах норми. Дані з поста спостереження м. Дрогобич (див. табл. 2) вказують на те, що за двома показниками - БСК та амоній-іони, $є$ перевищення в 1,73 і 5,2 раза відповідно. Надзвичайне перевищення спостерігається за показником нітритіонів - у 16,75 раза. Перевищення вмісту нітрит-іонів у поверхневих водоймах спричиняють отруєння тварин, особливо молодняку. Підвищений вміст нітритів вказує на посилення процесів розкладання органічних речовин в умовах повільного окислювання нітрит-іонів до нітрат-іонів, що свідчить про забруднення водного об'єкта, тобто $\epsilon$ важливим санітарним показником. Підвищення концентрації нітритів і іонів амонію у поверхневих водах вказує на нещодавнє забруднення, тоді як збільшення вмісту нітратів - на забруднення в минулому.

Дані з поста спостереження с. Сівка-Войнилівська (див. табл. 2) вказують на незначне перевищення нормативу показників БСК, сульфат-іонів, хлорид-іонів та амоній-іонів. А ось кількість завислих (суспендованих) речовин перевищує норму у 4,6 раза. Завислі речовини потрапляють у воду внаслідок процесів ерозії грунтів i гірських порід, скаламучення донних відкладень, розкладання гідробіонтів, хімічних реакцій, а також надходження 3 побутовими і виробничими стічними водами. Завислі речовини впливають на глибину проникнення сонячного світла, погіршують умови життєдіяльності гідробіонтів, призводять до замулювання водних об'єктів та спричиняють їх евтрофікацію.

Дані моніторингу з постів спостереження міст Хотин і Могилів-Подільський (див. табл. 2) свідчать, що жодних перевищень норм показників хімічних речовин немає. Дані з поста спостереження с. Шершенці (див. табл. 2) вказують на досить значне перевищення норм показника розчиненого кисню у 9,3 раза. Показник завислих речовин перевищує норми у 2,7 раза.

Дані $з$ поста спостереження с. Кучургани (див. табл. 2) вказують на значне перевищення показників сульфат-іонів, хлорид-іонів та амоній-іонів. Перевищення становить, відповідно, 4,27, 1,55 та 3,2 раза. Підвищений вміст сульфат-іонів, хлорид-іонів та амоній-іонів свідчить про потрапляння у річку значної кількості неочищених та недостатньо очищених господарсько-побутових стоків від приватного сектору та сільськогосподарського виробництва, які знижують здатність води природних водойм до самоочищення.

Визначення класу якості води за результатами моніторингу поверхневих вод з постів спостереження у селах Розвадів Львівської обл. та Маяки Одеської області. За даними середньорічних концентрацій забруднювальних речовин у контрольних створах водних об'єктів регіону за звітний рік розраховано ІЗВ та встановлено клас якості води у створах сіл Розвадів 
Львівської обл. та Маяки Одеської обл. (табл. 3, 4). Проведено порівняльну характеристику якості води за розрахованим ІЗВ вказаних водних об'єктів у 2016, 2018 та 2020 роках.

Табл. 3. ІЗВ та клас якості води (за даними з поста спостереження с. Розвадів Львівської обл.) / WPI and water quality class (according to the observation post in the village of Rozvadiv, Lviv region)

\begin{tabular}{|c|c|c|c|}
\hline Рік & $\begin{array}{c}\text { Величина } \\
\text { I3В }\end{array}$ & $\begin{array}{c}\text { Клас якості } \\
\text { води }\end{array}$ & $\begin{array}{c}\text { Характеристика } \\
\text { води }\end{array}$ \\
\hline 2016 & 1,9 & III & Помірно забруднена \\
\hline 2018 & 3,9 & IV & Забруднена \\
\hline 2020 & 1,3 & III & Помірно забруднена \\
\hline
\end{tabular}

Контрольний створ, розміщений у с. Розвадів Львівської області, характеризується у 2018 р. зростанням індексу забрудненості води порівняно з 2016 р., клас якості води змінюється з III - помірно забруднена на IV - забруднена вода. У 2020 р. спостерігається зменшення індексу забрудненості води порівняно 3 2018 р., клас якості води змінюється від IV - забруднена вода на III - помірно забруднена.

Табл. 4. ІЗВ та клас якості води (за даними 3 поста спостереження с. Маяки Одеської обл.) / WPI and water quality class (according to the observation post in the village of Mayaki, Odesa region)

\begin{tabular}{|c|c|c|c|}
\hline Рік & $\begin{array}{c}\text { Величина } \\
\text { IЗВ }\end{array}$ & $\begin{array}{c}\text { Клас якості } \\
\text { води }\end{array}$ & $\begin{array}{c}\text { Характеристика } \\
\text { води }\end{array}$ \\
\hline 2016 & 1,1 & III & Помірно забруднена \\
\hline 2018 & 0,9 & II & Чиста \\
\hline 2020 & 1,2 & III & Помірно забруднена \\
\hline
\end{tabular}

Контрольний створ, розміщений в с. Маяки Одеської області, характеризується у 2018 р. зниженням індексу забрудненості води порівняно з 2016 р. (клас якості води змінюється з III - помірно забруднена на II - чиста вода) та незначним зростанням індексу забрудненості води в 2020 р. порівняно з 2018 р. (клас якості води змінюється з II - чиста вода на III - помірно забруднена).

За визначеними значеннями індексу забрудненості води, можна вважати, що вода річки Дністер ще не досягла критичної межі забруднення і має потенціал до самоочищення. Водокористувачі повинні цей потенціал тільки підтримувати і покращувати. Для цього потрібно упереджувати можливість змиву з виробничих територій та формувати біологічний бар'єр для захисту водних об'єктів, для затримання та знешкодження надлишків біогенних елементів і токсичних сполук.

Для верхів'я річки Дністер (с. Розвадів Львівської області) характерні значно вищі значення індексу забрудненості води порівняно з долиною Дністра (с. Маяки Одеської області).

Обговорення результатів досліджсення. Отримані результати досліджень корелюють 3 наявними результатами досліджень, наведеними в працях $[4,11]$. Вода долини Дністра характеризується як "добра", чиста вода $з$ ухилом до класу "задовільної", слабко забрудненої прийнятної якості та "добра", чиста вода прийнятної якості. Також спостерігаються епізодичні перевищення гранично допустимих концентрацій біогенних елементів та підтверджується те, що клас якості води напряму залежить від антропогенного навантаження на водні ресурси $[1,5,7,9,10]$. Усунення недоліків сучасної системи моніторингу поверхневих вод за допомогою безперервного автоматизованого контролю якісних характе- ристик вод [8] тільки частково вирішить наявну проблему. На нашу думку, необхідною умовою забезпечення належної якості поверхневих вод є сувора законодавчо встановлена відповідальність за забруднення поверхневих вод виробничими стоками, а також господарськопобутовими стоками від приватного сектору та сільськогосподарського виробництва.

\section{Висновки / Conclusions}

Проаналізовано значення гідрохімічних показників по течії річки, починаючи з м. Самбір Львівської обл., завершуючи с. Кучургани Одеської обл. та встановлено перевищення за вмістом нітрит-іонів, сульфат-іонів, хлорид-іонів, амоній-іонів та показником біохімічного споживання кисню на окремих постах спостереження. За даними середньорічних концентрацій забруднювальних речовин у контрольних створах водних об'єктів регіону за звітний рік розраховано індекс забрудненості води та встановлено клас якості води у створах с. Розвадів Львівської обл. та с. Маяки Одеської обл. Проведено порівняльну характеристику якості води за розрахованим ІЗВ вказаних водних об'єктів у 2016, 2018 та 2020 роках. Для верхів'я річки Дністер (с. Розвадів Львівської області) характерні значно вищі значення індексу забрудненості води порівняно $з$ долиною Дністра (с. Маяки Одеської області). За визначеними значеннями індексу забрудненості води, можна вважати, що вода річки Дністер ще не досягла критичної межі забруднення і має потенціал до самоочищення. Отже, аналіз екологічного стану басейну Дністра та його тенденцій дає підставу зробити висновок, що переважно екстенсивне водоспоживання майже в усіх галузях національного господарства, зростання загальних обсягів непродуктивних витрат води, помітне скорочення потенціалу водних ресурсів внаслідок забруднення і виснаження водних джерел зумовлюють потребу впровадження широкомасштабних екологічних і господарських заходів 3 використання вод.

\section{References}

1. Bosak, P. V., Korol, K. A., \& Lutsyk, A. H. (2019). Ekolohichna kharakterystyka richok u Slavskomu Lvivskoi oblasti. Visnyk LDUBZhD (Lviv. derzh. un-tu bezpeky zhyttiediialnosti), 20, 80 84. https://doi.org/10.32447/20784643.20.2019.11

2. Kharytonov, M., Babenko, M., Sytnyk, S., \& Maslikova, K. (2019). Ecological assessment of water quality of Samotkan river in the area of polymetallic ores mining. Agrology, 2(1), 22-26. https://doi.org/10.32819/2617-6106.2018.14013

3. Liao, J., Chen, J., Ru, X., Chen, J., Wu, H., \& Wei, C. (2017). Heavy metals in river surface sediments affected with multiple pollution sources, South China: distribution, enrichment and source apportionment. Journal of Geochemical Exploration, 176, 9-19. https://doi.org/10.1016/i.gexplo.2016.08.013

4. Linnik, P. N., Morozova, A. A., \& Osipenko, V. P. (2019). Gidrokhimicheskie issledovaniia rek i vodoemov basseina Dnestra v retrospektive i sovremennykh usloviiakh. Gidrobiologichnii zhurnal, 6, 82-102. [In Russian].

5. Madzhd, S. M., \& Kulynych, Ya. I. (2017). Dynamika zmin znakhodzhennia rechovyn ta elementiv tekhnohennoho pokhodzhennia u vodakh. Irpin. Problemy khimmotolohii: materialy VI Mizhn. nauk.-tekhn. konf., (Lvivska obl., 19-23 chervnia 2017). Kyiv Lvivska obl., 401-404. [In Ukrainian].

6. Morales, M. M., Martih, P., Llopis, A., Campos, L., \& Sagrado, J. (1999). An environmental study by factor analysis of surface seawater in the Gulf of Valencia (western Mediteranean). Anal Chim Acta, 394, 109-17. https://doi.org/10.1016/S00032670(99)00198-1 
7. Nesterova, O. V., Sharkov, V. V., Zhuravlova, O. A., \& Nesterov, Ya. S. (2019). Problemy baseiniv malykh richok. Visnyk Prydniprovskoi derzhavnoi akademii budivnytstva ta arkhitektury, 5, 257258. https://doi.org/10.30838/J.BPSACEA.2312.221019.68.524

8. Odnorih, Z. S., Manko, R. V., Malovanyi, M. S., \& Solovii, Kh. M. (2020). Ekolohichnyi monitorynh poverkhnevykh vod baseinu richky Zakhidnyi Buh u stvorakh Lvivskoi oblasti (2018-2019 rr.). Kolektyvna monohrafiia "Stalyi rozvytok: Zakhyst navkolyshnoho seredovyshcha. Enerhooshchadnist. Zbalansovane pryrodokorystuvannia". Lviv: TzOV "ZUKTs", 80-96. [In Ukrainian].

9. Pylypovych, O. V., \& Kovalchuk, I. P. (2017). Heoekolohiia richkovo-baseinovoi systemy verkhnoho Dnistra: monohrafiia. Lviv-Kyiv: LNU imeni Ivana Franka, 284 p. [In Ukrainian].

10. Pylypovych, O., Rutar, A., Petrovska, M., \& Andreichuk, Yu. (2019). Otsinka yakosti poverkhnevykh vod transkordonnoi richky Viar. Hidrolohiia, hidrokhimiia i hidroekolohiia, 1(52), 75-87. [In Ukrainian].

11. Romanchuk, M. Ye., Tkach, K. S., Polishchuk, A. A., \& Kolisnyk, A. V. (2015). Otsinka yakosti vody. Dnister-vodozabir za hidrokhimichnymy pokaznykamy protiahom 1998-2012 rr. ta osoblyvosti zmin biohennykh rechovyn za kharakterni po vodnosti roky. Visnyk Odeskoho derzhavnoho ekolohichnoho universyte$t u, 19,114-119$. [In Ukrainian].

12. Sharma, A., Bora, C., \& Shukla, V. (2013). Evaluation of seasonal changes in physico-chemical and bacteriological characteristics of water from the Narmada River (India) using multivariate analysis. Nat. Resour. Res., 22, 283-296. https://doi.org/10.1007/s11053013-9204-X

13. Shrestha, S., \& Kazama, F. (2007). Assessment of surface water quality using multivariate statistical techniques: A case study of the fuji river basin, Japan. Environ. Model. Softw., 22, 464 475. https://doi.org/10.1016/i.envsoft.2006.02.001

14. Xu, S., Huang, B., Wei, Z. B., Luo, J., Miao, A. J., \& Yang, L. Y. (2013). Seasonal variation of phytoplankton nutrient limitation in Lake Taihu, China: A monthly study from year 2011 to 2012. Ecotoxicol. Environ. Saf., 94, 190-196. https://doi.org/10.1016/j.ecoenv.2013.05.006

15. Yatsyk, A. V., \& Romanenko, V. D. (2008). Metodyka otsinky yakosti poverkhnevykh vod za vidpovidnymy katehoriiamy. Kyiv, 28 p. [In Ukrainian].

\section{A. M. Shybanova1, V. D. Pohrebennyk1, O. P. Mitryasova', M. V. Ruda', E. A. Dzhumelya1, M. M. Paslavskyi ${ }^{3}$ \\ ${ }^{1}$ Lviv Polytechnic National University, Lviv, Ukraine \\ ${ }^{2}$ Named after Petro Mohyla Black Sea National University, Mykolaiv, Ukraine \\ ${ }^{3}$ Ukrainian National Forestry University, Lviv, Ukraine}

\section{ECOLOGICAL ASSESSMENT OF THE DNISTER RIVER WATER QUALITY}

A comprehensive study of the problems of nature management is especially relevant for regions with a high degree of economic development of natural resources and their intensive and long-term exploitation. Intense anthropogenic pressure on the environment has caused a violation of the natural balance in the Dniester River basin. The purpose of this study is to assess the ecological status of the Dniester River. To achieve this goal, the degree of exceeding the maximum allowable concentrations of nitrite ions, sulphate ions, chloride ions, ammonium ions and the biochemical consumption of oxygen in the water of the river control points at individual observation posts is revealed. The content of nitrite ions was exceeded 4.5 times at the observation post in Sambir and 16.75 times at the observation post in Drohobych. Data from the observation post in Sivka-Voynilivska indicates a slight excess of the standard indicators of BOD, sulphate ions, chloride ions and ammonium ions. But the number of suspended substances exceeds the norm by 4.6 times. Monitoring data from the observation post in Mohyliv-Podilskyi shows that there is no significant exceedance of chemicals as in the case of the observation post in Khotyn. Data from the observation post in Shershentsi indicates a fairly significant excess of dissolved oxygen by 9.3 times. The indicator of suspended solids exceeds the norms by 2.7 times. Data from the observation post in Kuchurgany indicates a significant excess of sulphate ions, chloride ions and ammonium ions. The excess is 4.27 , 1.55 and 3.2 times, respectively. According to the average annual concentrations of pollutants in the control areas of the Dniester River for the reporting year, the index of water pollution was calculated and the water quality class in the areas of the village of Rozvadiv, Lviv Region and with Mayaki of Odessa Region The comparative characteristic of water quality according to the calculated index of water pollution at the specified observation posts is carried out. It is established that the Dniester River valley is characterized by much lower values of the water pollution index compared to the upper Dniester. The waters of the Dniester River basin are in most cases characterized as moderately polluted and are under significant anthropogenic impact, the level of which is close to the limit of ecosystem resilience. According to certain values of the water pollution index, we can assume that the water of the Dniester River has not yet reached the critical limit of pollution and has the potential for self-purification.

Keywords: the Dniester River; observation posts; water pollution index; water quality class. 